
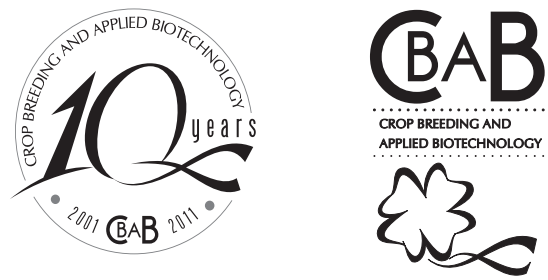

\title{
Breeding tropical forages
}

\author{
L Jank $^{1 *}$, CB Valle ${ }^{1}$ and RMS Resende ${ }^{1}$
}

Received 1 April 2011

Accepted 19 May 2011

\begin{abstract}
Brazil has the largest commercial beef cattle herd and is the main beef exporter in the world. Cultivated pastures are the basis for the Brazilian beef production, and occupy an area of 101.4 million hectares. However, very few forage cultivars are commercially available, and the majority of these are of apomictic reproduction, thus genetically homogeneous. Tropical forage breeding is at its infancy, but much investment and efforts have been applied in the last three decades and some new cultivars have been released. In this paper, origin of different species, modes of reproduction, breeding programs and targets are discussed and the resulting new cultivars released are presented.
\end{abstract}

Key words: Arachis, Brachiaria, Panicum maximum, Pennisetum, Stylosanthes.

\section{INTRODUCTION}

Approximately half the world bovine meat production comes from tropical and subtropical countries which had a three-fold increase in beef and veal production in the last 40 years (FAOSTAT 2011). Animal production in tropical and subtropical areas of the world is largely dependent on either native or planted pastures therefore the demand for high quality, productive and adapted forages is high. In Brazil, there were 205 million heads of cattle in 2009 (IBGE 2011) and it is the largest commercial beef cattle herd in the world, equivalent to $14.8 \%$ of the world's herd (FAOSTAT 2011). Since 2004, Brazil has also consolidated itself in the international beef market and has become the main beef exporter in the world, with a competitive advantage due to cattle production being done exclusively on pasture, thus attending the market concern for food and feed security.
Cultivated pastures are the basis for the Brazilian beef production. They occupy an area of 101.4 million hectares (IBGE 2011), which together with the native pastures is equivalent to all the area planted to permanent and temporary crops plus planted and natural forests. Another consequence of all this is the great development of the Brazilian tropical forage seed industry, which became the leader world exporter of this type of seed.

The considerable status of the Brazilian cattle industry in the world is due to three main reasons: favorable soil and climatic conditions for cattle rearing, the use of continuously improved cattle breeds adapted to tropical conditions, and finally the solidity of forage introduction, evaluation and selection programs, which resulted in the release of highly adapted and productive forages.

Nevertheless, still few forage cultivars are commercially available, and the majority of these are of apomictic reproduction, thus genetically homogeneous

\footnotetext{
${ }^{1}$ Embrapa Gado de Corte, CP 154, 79.002-970, Campo Grande, MS, Brazil. *E-mail: liana@ cnpgc.embrapa.br
} 
and not generating novel variation. This is a threat to national security due to a possible emergence of new pests and diseases or break of resistance to known diseases. Thus the release of new improved cultivars is in high demand to diversify pastures and alleviate this problem. Additionally, Brazil has approximately 50 percent of the pastures in various stages of degradation (Dias Filho 2007), which would benefit from the substitution by new improved cultivars. This shows that there is still room for the expansion of the cattle industry, without the need of expansion of new areas of pasture.

The discontinuity of investment on the tropical pasture programs of the two leading institutions worldwide, the International Center for Tropical Agriculture (CIAT) in Colombia, and the Commonwealth Scientific and Industrial Research Organization (CSIRO) in Australia, has placed Brazil as the leader in tropical forage breeding in the world. The most significant programs are led by Embrapa (Brazilian Agricultural Research Corporation) which invested in various forage genera in the last three decades, and today, more than $70 \%$ of the cultivars in use were released by Embrapa and partners (Valle et al. 2009).

\section{LITERATURE REVIEW}

Most cultivars of tropical grasses available commercially are wild ecotypes selected from natural diversity (Hacker and Jank 1998). However, there is much yet to be explored from the variability found in the available germplasm. Breeding is the key for future development of superior forages, but breeding is only justified after the germplasm of a genus or species has been explored and specific problems identified (Cameron 1983). It is premature to begin hybridization programs of a species prior to its wide use in production systems, or before large germplasm resources are available and have been evaluated. The tropical world has still to profit from the genetic manipulation of tropical forages through breeding, and possibilities are endless.

Forages comprehend various species of mainly grasses and legumes. Forage grasses are planted exclusively in a pasture, or in a mixture with forage legumes which fix atmospheric nitrogen and benefit both the grass and the soil. Different grass and legume species are suitable and adapted to different soil and climate conditions and the use of various cultivars and species is recommended in the same property so as to avoid monoculture and at the same time, make the best use of the ecosystem and explore the species/cultivar potential by different animal categories.

The science of forage breeding in tropical countries is still very young and has been intensified only in the last decades. Forages have not yet been domesticated (as to seed retention and absence of anti-quality compounds for example), thus continuous cycles of cultivation and selection to fit human needs are still required. There is yet little knowledge on the genetic control of agronomic traits to be improved, as well as the development of efficient specific breeding methods.

Forage breeding is very complex, because merit criteria are not straightforward as in grain crops, since they can only be assessed after conversion to animal products, such as milk or meat. Merit also depends on cocoordinated effort of teamwork, over a wide range of ecosystems to ascertain $\mathrm{G} \times \mathrm{E}$ interaction and involves time-consuming and costly evaluations under grazing. It is indisputable that cultivars developed from germplasm collections, followed by plot evaluation, regional trials and finally animal performance trials in pastures prior to release be considered of high priority for the adoption and success of forage-based technologies (Jank et al. 2005b).

The release of tropical forages in Brazil is regulated by the Ministry of Agriculture, Livestock and Food Supply. A two-year evaluation under cutting and a further twoyear evaluation under grazing in comparison to a standard released cultivar are necessary to receive the authorization for release and commercialization in the country. An experiment of Distinctiveness, Homogeneity and Stability (DHE) is necessary to apply for cultivar protection and to receive the benefits of royalties over the commercialization of seeds.

\section{REPRODUCTIVEBEHAVIOR}

Around $60 \%$ of the tropical grass species reproduce by apomixis. Apomixis is a clonal propagation by seeds, in which plants identical to the mother plant are produced. Therefore, a pasture planted to an apomictic species is always uniform. In apomixis, parthenogenesis occurs inside the ovary since all cells in the meiotic tetrad abort and one or several non-reduced cells from the nucellus develop into embryo-sacs. Pseudogamy then occurs, where the pollen only fertilizes the polar nuclei but not the egg cell. Apomixis of the Panicum type is determined by a gene or group of genes in a simple inheritance and the 
progeny of a cross between sexual $\mathrm{x}$ apomictic plants always yield sexual and apomictic plants in the ratio 1:1. The advantage of this system, is that if an excellent apomictic hybrid arises in the first generation, it may be released, since its hybrid vigor will be fixed. Tropical forage grasses that reproduce by apomixes include Brachiaria brizantha, B. decumbens, B. humidicola, Panicum maximum, Hyparrhenia rufa, Melinis minutiflora, Cenchrus ciliaris and many Paspalum species.

Collection of apomictic species in the center of origin is essential because breeding depends on variability but essentially on the availability of sexual plants. These may be found in the center of origin and in $P$. maximum, $B$. brizantha and $B$. decumbens are usually diploid in nature (Savidan 1982, Simioni and Valle 2009). Their chromosome numbers must be artificially doubled so that they may be crossed with tetraploid apomictic plants. An exception is B. humidicola, in which the sexual plant found in the Center of Origin is hexaploid, just as the apomictic accessions (Valle et al. 2009).

Other tropical grasses as Pennisetum purpureum, Setaria sphacelata, Andropogon gayanus, Hemarthria altissima, Chloris gayana, Cynodon spp. and Digitaria decumbens reproduce by allogamy.

Tropical forage legumes reproduce generally by autogamy, however, many also present high levels of cross-pollination. It is essential that the reproductive system of the species and the population in the breeding program be determined, so that the most suitable breeding method may be used. Thus, it was found that Stylosanthes capitata in Brazil presented $31 \%$ outcrossing (Chiari et al. 2010) and S. guianensis presented from $26 \%$ to $38.6 \%$ based on RAPD or microssatellite (Chiari et al 2010, SantosGarcia et al. 2010). Various other legumes presented from $4 \%$ outcrossing in Desmodium heterocarpon until $23 \%$ in Centrosema gyroides (Maass and Torres 1998). In C. virginianum, outcrossing rates varied from 0 to $89 \%$ in different accessions (Maass and Torres 1998).

\section{GENETIC RESOURCES}

Tropical forage grasses, with the exception of Paspalum spp. and Axonopus spp. are originally from Africa where they evolved under the hoofs of large animals, as giraffes, elephants, rhinoceros, and several ruminants, where they were selected to tolerate grazing habits and became productive, vigorous and robust. South American grasses, as Paspalum spp. and Axonopus spp on the other hand, evolved under pressure from smaller animals, so they are generally less productive and vigorous and do not withstand overgrazing.

Apomictic forage grasses display wide variation in nature, however, little of this diversity has been sampled (Savidan 2000). The first species intensively collected was P. maximum in East Africa by the French Institute of Research for Development (Former ORSTOM - Office de la Recherche Scientifique et Technique d'Outre-Mer) (Combes and Pernès 1970), and later by the Japanese Hojito and Horibata (1982). Thus the diversity of this species is well represented in ex situ collections (Savidan et al. 1989). Brachiaria was also extensively collected by CIAT in East Africa (Keller-Grein et al. 1996), but important species as $B$. mutica and sexual pools of $B$. brizantha and $B$. humidicola are still lacking, thus the existing collection cannot be considered representative of the natural distribution. The genus Paspalum spp. of South American origin, has also been extensively collected by the Brazilian Agricultural Research Corporation (Embrapa) but the complete collection of ca. 1600 accessions has not been fully characterized to determine if this genebank is representative or not.

Genera such as Pennisetum, Hyparrhenia, Melinis, Setaria, Andropogon, Hemarthria, Chloris, and Cenchrus should be included in forthcoming collecting efforts to ensure enough diversity for future improvement efforts and sexual forms within apomictic Hyparrhenia and Melinis must be sought (Jank et al. 2005a).

Most forage legumes are originated in Tropical America. The region between Mexico and the Caribbean to the north of Argentina is considered the greatest centre of origin and diversity of tropical legumes with forage potential in the world (Paterson 1987). Legumes from this region are Arachis spp., Centrosema spp., Desmodium spp., Stylosanthes spp., Calopogonium, Leucaena, Macroptilium and Galactia striata (Valls and Pizarro 1994). Since late 1970's Embrapa alone or with CIAT have organized numerous collection trips in Brazil and assembled a good quantity of forage legume accessions. Other important legumes, such as Pueraria and Neonotonia wightii are originated in east Asia and Africa, respectively (Harlan 1983).

\section{BREEDING PROGRAMS AND TARGETS}

Breeding of forages have similar targets to those of crops such as increased productivity and quality, resistance to pests and diseases, efficient use of fertilizers, and 
adaptation to edaphic and climatic stresses. However, it has additional requisites since forages have no intrinsic value unless converted into animal products (meat, milk, hide, calves), which implies indirect evaluation to verify worth. Through the years, selection has involved the choice of the most vigorous plants, and field-oriented selection has contributed greatly to genetic advance.

The main objective of forage breeding programs thus far has been improvement of forage yield and quality (Hacker and Jank 1998). Whereas direct selection has resulted in the release of cultivars 80 to $130 \%$ more productive in terms of leaf yield than the commercial standard, bred cultivars have also led to $26 \%$ increase in digestibility and $47 \%$ in productivity (Burton 1989, Burton et al. 1993, Jank et al. 2005a). Improvement for yield and quality have direct benefits to the farmers by improving animal performance. Thus the adoption of released cultivars have resulted in increases in $6 \%$ milk production, and 7.7 to $37.6 \%$ liveweight gain per area (Embrapa Gado de Corte 1990, Lowe et al. 1991).

Seed production is also a factor considered in breeding programs. Poor seed production results in high seed prices and consequently little adoption. This was the case with many good legume cultivars released, and recently with Brachiaria hybrid cv. Mulato (Miles 1999). Despite the use of vegetative propagation in certain systems and in some countries, seed producing cultivars are easier to establish, faster to be adopted and much more widespread.

Few tropical breeding programs are underway outside Brazil. The breeding programs in Brazil, and especially at Embrapa, are divided into genera/species which are distributed in the different Research Centers. These programs and their breeding targets are shown on Table 1.

The $B$. brizantha breeding programs at CIAT and Embrapa, Brazil, intend to select hybrids which combine the qualities of three species: the high forage quality and determined flowering cycle of $B$. ruziziensis, the yield and resistance to spittlebug of $B$. brizantha and the vigor and adaptation to acid, infertile soils of $B$. decumbens (Miles and Valle 1996, Miles 1999, Valle et al. 2010). Crosses are made using $B$. ruziziensis sexual accessions that were artificially doubled with colchicine in Belgium (Lutts et al. 1994).

The B. brizantha germplasm in Brazil received form CIAT total 223 accessions. The ploidy level characterization of this germplasm resulted in the discovery of a sexual accession, which was artificially doubled to make crosses with tetraploid accessions feasible (Pinheiro et al. 2000). However, these plants flower much later than the $B$. brizantha accessions, so crosses have not yet been successful despite attempts to synchronize flowering of the progenitors.

Diploid sexual $B$. decumbens accessions have also been discovered in the $B$. decumbens germplasm collection at Embrapa Beef Cattle. One of these accessions has been doubled and was successfully crossed to the most important tetraploid apomictic accessions. Ca. 480 hybrids from this cross are presently being evaluated in the field (Valle, personal communication).

The $B$. humidicola germplasm at Embrapa Beef Cattle is composed of 58 accessions. Recent cytogenetic studies have shown that this species is hexaploid and has a different base number $(\mathrm{n}=6)$ than the other three important Brachiaria species (n=9) (B. brizantha, B. decumbens and B. ruziziensis) (Boldrini et al. 2009). In this case, the sexual plant found in nature has the same chromosome number as the main apomictic accessions. About 300 hybrids from the cross between this sexual plant and an accession selected from the germplasm are under agronomic evaluation.

The $B$. ruziziensis is a sexual diploid accession and the germplasm is composed of about 50 accessions. This species is very promising for integration with crops, thus breeding at Embrapa Dairy Cattle involves recurrent selection of populations selected for leafiness, vigor, persistence and spittlebug resistance (Souza et al. 2010).

Artificially duplicated sexual plants of $P$. maximum are available for breeding. Selected sexual plants have been introduced at Embrapa Beef Cattle with the IRD collection of 426 apomictic accessions and have been evaluated in half-sib progeny tests to select the best progenitors (Martuscello et al. 2009). Approximately four hundred hybrids from the crosses of two of the best sexual plants and cultivars Tanzania and Mombaça are currently under agronomic evaluation in the field (Jank 2010, personal communication).

One of the objectives of the $P$. purpureum breeding programs in Brazil is selection of seed producing cultivars, which are obtained by crossing P. purpureum and P. glaucum (L.) R. Br. The progenies from this cross are triploid and sterile, but once doubled by colchicine become hexaploid and fertile (Pereira and Lédo 2008). A selected population is being developed for release. The challenge is to increase the seed production and make the population uniform. 
Table 1. Main forage breeding programs in Brazil and targets

\begin{tabular}{|c|c|c|c|}
\hline Species & Research Center & Breeding target & References \\
\hline Arachis spp. & $\begin{array}{l}\text { Embrapa Acre, Rio } \\
\text { Branco/AC }\end{array}$ & $\begin{array}{l}\text { Yield, soil cover, resistance to } \\
\text { pests and diseases, seed } \\
\text { production }\end{array}$ & Assis et al. (2008) \\
\hline Brachiaria brizantha & $\begin{array}{l}\text { Embrapa Beef Cattle, } \\
\text { Campo Grande/MS }\end{array}$ & $\begin{array}{l}\text { Spittlebug resistance, nutritive } \\
\text { value, adaptation to acid soils, } \\
\text { seed yield }\end{array}$ & $\begin{array}{l}\text { Miles and Valle (1996), Valle } \\
\text { et al. (2009) }\end{array}$ \\
\hline Brachiaria brizantha & CIAT, Cali/Colombia & $\begin{array}{l}\text { Spittlebug resistance, nutritive } \\
\text { value, adaptation to acid soils, } \\
\text { seed yield }\end{array}$ & $\begin{array}{l}\text { Miles (1999), Valle et al. } \\
\text { (2009) }\end{array}$ \\
\hline Brachiaria decumbens & $\begin{array}{l}\text { Embrapa Beef Cattle, } \\
\text { Campo Grande/MS }\end{array}$ & $\begin{array}{l}\text { Spittlebug resistance, Nutritive } \\
\text { value }\end{array}$ & $\begin{array}{l}\text { Valle et al. (2009), Valle et al. } \\
(2010)\end{array}$ \\
\hline Brachiaria humidicola & $\begin{array}{l}\text { Embrapa Beef Cattle, } \\
\text { Campo Grande/MS }\end{array}$ & Yield, nutritive value & Valle et al. (2009) \\
\hline Brachiaria ruziziensis & $\begin{array}{l}\text { Embrapa Dairy Cattle, Juiz } \\
\text { de Fora/MG }\end{array}$ & $\begin{array}{l}\text { leafiness, vigor, persistence, } \\
\text { spittlebug resistance }\end{array}$ & Souza et al. (2010) \\
\hline Panicum maximum & $\begin{array}{l}\text { Embrapa Beef Cattle, } \\
\text { Campo Grande/MS }\end{array}$ & $\begin{array}{l}\text { Leaf and seed yield, Bipolaris } \\
\text { maydis resistance, energy. }\end{array}$ & $\begin{array}{l}\text { Jank et al. (2005a), Jank et al. } \\
\text { (2008), Resende et al. (2004) }\end{array}$ \\
\hline Pennisetum spp. & $\begin{array}{l}\text { Embrapa Dairy Cattle, Juiz } \\
\text { de Fora/MG }\end{array}$ & Seed yield, cut and carry, energy & Pereira and Lédo (2008) \\
\hline Stylosanthes capitata & $\begin{array}{l}\text { Embrapa Beef Cattle, } \\
\text { Campo Grande/MS }\end{array}$ & $\begin{array}{l}\text { Seed yield, dry matter yield, } \\
\text { anthracnose resistance }\end{array}$ & $\begin{array}{l}\text { Embrapa Gado de Corte } \\
\text { (2007), Simeão et al. (2006) }\end{array}$ \\
\hline Stylosanthes guianensis & $\begin{array}{l}\text { Embrapa Cerrados, } \\
\text { Planaltina/DF }\end{array}$ & Seed yield, dry matter yield & Simeão et al. (2006) \\
\hline Stylosanthes macrocephala & $\begin{array}{l}\text { Embrapa Beef Cattle, } \\
\text { Campo Grande/MS }\end{array}$ & Anthracnose resistance, seed yield & $\begin{array}{l}\text { Embrapa Gado de Corte } \\
(2007)\end{array}$ \\
\hline
\end{tabular}

Seed production is also the breeding target of the Stylosanthes and Arachis programs. The Stylosanthes germplasm is composed of accessions of the species $S$. scabra, S. macrocephala, S. capitata and S. guianensis, and especially the latter has as challenge the increased production of seeds so that prices may be affordable for the consumer. The Arachis germplasm at Embrapa Acre has ca. 97 accessions of A. pintoi. The cultivars presently available in the market, are propagated vegetatively. A good seed producing accession is being evaluated for release.

\section{MAIN RESULTS}

Embrapa has invested in tropical forage collection, introduction, characterization and breeding since the 1970's. In 1984, a B. brizantha cultivar, received from Zimbabwe was released commercially. This cultivar Marandu, due to its productivity, adaptation, ease of management, seed production and resistance to spittlebugs became the number one cultivar in land extension and seed commercialization. It is estimated that $35 \%$ of the seeds commercialized in the country are of this cultivar. However, problems of pasture death have been arising, mainly in the north of the country and new cultivars are being recommended (Barbosa 2006).

Brachiaria is the most commercialized genus in Brazil, followed by P. maximum cultivars. They are responsible for approximately $86 \%$ and $10 \%$ of the commercialized seed in the country, respectively.

From the Brachiaria germplasm, three cultivars have been released. Brachiaria brizantha cvs. Xaraés and Piatã were released in 2003 and 2007, respectively. Cultivar Xaraés is more productive and results in higher weight gains per area due to its higher animal carrying capacity. It is also later flowering allowing for a longer period of grazing in the rainy season. Cultivar Piatã has a higher nutritive quality and results in higher liveweight gain per animal. It is also more tolerant to waterlogged soils than cv. Marandu. Brachiaria humidicola cv. Tupi, released in 2011, is more productive than common B. humidicola.

Three $P$. maximum cultivars have been released from the germplasm: cvs. Tanzania, Mombaça and Massai in 1990, 1993 and 2000, respectively. The first two accessions total $10 \%$ percent of the seed market in the country and 
are being exported to 26 other Latin American countries. Cultivar Tanzânia-1 is of medium size, 80 percent more productive than the traditional $\mathrm{cv}$. Colonião, and more easily managed in comparison with other cultivars of the same species. Cv. Mombaça is 130 percent more productive than Colonião, and used in intensive production systems with rotational pasture management. Cv. Massai, in contrast, is very short, maximum $90 \mathrm{~cm}$ height, with thin leaves and is used for pasture diversification and grazing of cattle, horses, sheep and goats (Jank et al. 2008, Jank et al. 2010).

Stylosanthes cv. Campo Grande was released in 2000 after many cycles of breeding among 17 anthracnoseresistant Brazilian and Venezuelan S. capitata accessions, and among $6 \mathrm{~S}$. macrocephala accessions. This cultivar is a physical mixture of the two species, in the proportion 80:20 by weight, respectively (Embrapa Gado de Corte 2007). Breeding also involved improvement of seed production, so that it could be machine harvested. It is estimated than there are 1.5 million hectares planted in Brazil in association to this legume.

\section{FINAL CONSIDERATIONS}

Tropical forage breeding is a very young science. Only in the last three decades, the germplasm collections were organized, accessions characterized, data documented and seeds conserved in the short and long terms. The collections under the care of breeders, guarantees that the accessions will be used in the breeding programs. Breeding efforts have been intensified in Brazil in the last years, by the hiring of new breeders and association with the private industry for financial assistance. Progress is expected in the next years, with the development of new and adapted technology in breeding, the development of superior new cultivars and consequently the expansion of the cattle industry. The tropical world should benefit from the release of new cultivars in the following decades.

As a young science, forage breeding courses in Universities in the Tropics are still lacking to develop academic expertise, but as more researchers from crop breeding are drawn to tropical grass breeding, this scenario should change in the future.

Breeding targets have been to increase yield and quality in the past years, since tropical grasses, in general, present broad adaptation in Brazil. However, breeding should move towards selection for specific conditions and uses, as the new tendencies of climate change and mitigation result in selection of forages for adaptation to biotic and abiotic stresses such as drought, water logging, aluminum tolerance, nitrification inhibition, decreased lignin concentration, etc, Also, nowadays other needs for forage grasses arise, such as breeding for ethanol and energy production.

The use of improved forages, selected and bred for increased quality, through increased digestibility and soluble carbohydrates, will result in an increased voluntary intake by the grazing animals, and a decrease as great as $28 \%$ in the emission of green-house gases may be expected. The potential of mitigation in the emission of green house gases through breeding of tropical forage species remains practically unexplored, and this approach may be very successful.

The need for new more productive and efficient cultivars in the short time is accelerating the search for new tools to help in the selection process. Thus, marker assisted selection and other technologies are becoming ever increasingly important. Molecular markers are being developed and used for characterization of the germplasm, fingerprinting of selected accessions, identification of hybrids, selection of progenitors, and also genome mapping of the species after phenotyping of bred populations. Other molecular techniques, as genomics and proteomics are being developed for various characteristics in the different species. In the medium to long term, the tropical world should also benefit from less lignified quality improved transgenic cultivars. 


\section{Melhoramento de forrageiras tropicais}

RESUMO - O Brasil tem o maior rebanho bovino comercial e é o principal exportador de carne do mundo. Pastagens cultivadas são a base para a produção de carne brasileira, e ocupam uma área de 101,4 milhões de hectares. Entretanto, poucas cultivares de forrageiras estão disponíveis comercialmente, e a maioria delas são de reprodução por apomixia, portanto, geneticamente homogêneas. O melhoramento de forrageiras tropicais ainda está na sua infância, porém muitos esforços e investimentos foram despendidos nas últimas três décadas e algumas novas cultivares foram lançadas. Neste trabalho são apresentados e discutidos a origem das diferentes espécies, o modo reprodutivo, os programas de melhoramento e as novas cultivares resultantes lançadas.

Palavras-chave: Arachis, Brachiaria, Panicum maximum, Pennisetum, Stylosanthes.

\section{REFERENCES}

Assis GML, Valentim JF, Carneiro Junior JM, Azevedo JMA and Ferreira AS (2008) Seleção de genótipos de amendoim forrageiro para cobertura do solo e produção de biomassa aérea no período de estabelecimento utilizando metodologia de modelos mistos. Brazilian Journal of Animal Science 37: 1905-1911.

Barbosa RA (2006) Morte de pastos de braquiárias. Embrapa Gado de Corte, Campo Grande, 206p.

Boldrini KR, Pagliarini MS and Valle CB (2009) Meiotic behavior of a nonaploid accession endorses $\mathrm{x}=6$ for Brachiaria humidicola. Genetics and Molecular Research 8: 14441450 .

Burton GW (1989) Registration of 'Tifton 9' Pensacola bahiagrass. Crop Science 29: 1326.

Burton GW, Gates RN and Hill GM (1993) Registration of 'Tifton 85' bermudagrass. Crop Science 33: 644.

Cameron DF (1983) To breed or not to breed. In McIvor JG and Bray RA (eds.) Genetic Resources of forage plants. CSIRO, Melbourne, p. 237-337.

Chiari L, Resende RMS and Matida ET (2010) Mating system parameters in Stylosanthes guianensis(Aubl.) Sw. based on RAPD markers. African Journal of Biotechnology 9: 5820-5822.

Combes D and Pernès J (1970) Variations dans le nombres chromosomiques du Panicum maximum Jacq. en relation avec le mode de reproduction (Variation in the number of chromosomes in Panicum maximum Jacq. in relation to mode of reproduction). Comptes Rendues Academie des Sciences 270: $782-785$

Dias Filho MB (2007) Degradação das pastagens: processos, causas e estratégias de recuperação. Embrapa Amazônia Oriental, Belém, 190p.

Embrapa Gado de Corte (1990) Capim Tanzânia-1. Uma opção para a diversificação das pastagens. Embrapa Gado de Corte, Campo Grande, 1 folder.
Embrapa Gado de Corte (2007) Cultivo e uso do estilosantescampo-grande. Embrapa Gado de Corte, Campo Grande, 11p. (Comunicado Técnico 105)

FAOSTAT data (2011) Available at <http://faostat.fao.org/site/ 573/DesktopDefault.aspx ?PageID=573\#ancor $>$ Assessed on Mar. 12, 2011.

Hacker JB and Jank L (1998) Breeding tropical and subtropical forage plants. In Cherney JH and Cherney DJR (eds.) Grass for dairy cattle. CABI, Wallingford, p. 49-71.

Harlan JR (1983) The scope for collection and improvement of forage plants. In McIvor JG and Bray RA (eds.) Genetic resources of forage plants. Commonwealth Scientific and Industrial Research Organization, East Melbourne, p. 3-14

Hojito S and Horibata T (1982) Plant exploration, collection and introduction from Africa. In: Tropical Agriculture Research Center - Nekken Shiryo 58: 1-120

IBGE (2011) Pesquisa Pecuária Municipal (1974 - 2009). Available at <http://www.sidra.ibge.gov.br/bda/tabela/listabl. asp?c=73\&z=p\&o=23> Assessed on Mar. 12, 2011.

Jank L, Martuscello JA, Resende RMS and Valle CB (2010) Panicum maximum Jacq. In Fonseca DM and Martuscello JA (eds.) Plantas forrageiras. Editora UFV, Viçosa, p. 166-194.

Jank L, Valle CB and Carvalho PF (2005a) New grasses and legumes: advances and perspectives for the tropical zones of Latin America. In Reynolds SG and Frame J (eds.) Grasslands: developments, opportunities and perspectives. FAO, Rome, p. 55-79

Jank L, Valle CB and Resende RMS (2005b) Grass and forage plant improvement in the tropics and sub-tropics. In McGilloway DA (ed). Grassland: a global resource. Wageningen Academic Publishers, Wageningen, p. 69-81.

Jank L, Resende RMS, Valle CB, Resende MDV, Chiari L, Cancado LJ and Simioni C (2008) Melhoramento Genético de Panicum maximum Jacq. In Resende RMS, Valle CB and Jank L (eds.) Melhoramento de forrageiras tropicais. Embrapa Gado de Corte, Campo Grande, p. 55-87. 
Keller-Grein G, Maass BL and Hanson J (1996) Natural variation in Brachiaria and existing germplasm collections. In Miles JW, Maass BL and Valle CB (eds.) Brachiaria: biology, agronomy, and improvement. CIAT, Cali, p. 16-42 (Publication 259).

Lowe KF, Moss RJ, Cowan RT, Minson DJ and Hacker JB (1991) Selecting for nutritive value in Digitaria milanjiana 4. Milk production from an elite genotype compared with Digitaria eriantha ssp. pentzii (pangola grass). Australian Journal of Experimental Agriculture 31: 603-608.

Lutts S, Ndikumana J and Louant BP (1994) Male and female sporogenesis and gametogenesis in apomictic Brachiaria brizantha, Brachiaria decumbens and $\mathrm{F}_{1}$ hybrids with sexual colchicine induced tetraploid Brachiaria ruziziensis. Euphytica 78: $19-25$.

Maass BL and Torres AM (1998) Off-types indicate natural outcrossing on five tropical forage legumes in Colombia. Tropical Grasslands 32: 124-130.

Martuscello JA, Jank L, Fonseca DM, Cruz CD and Cunha DNFV (2009) Among and within family selection and combined halfsib family selection in Panicum maximum Jacq. Brazilian Journal of Animal Science 38: 1870-1877.

Miles JW (1999) Nuevos híbridos de Brachiaria. (New hybrids of Brachiaria). Pasturas Tropicales 21: 78-80.

Miles, JW and Valle CB (1996) Manipulation of apomixis in Brachiaria breeding. In Miles JW, Maass BL and Valle CB (eds.) Brachiaria: biology, agronomy, and improvement. CIAT, Cali, p. 164-177 (Publication 259).

Paterson RY (1987) Genetic resources of tropical pasture. In Moore JE, Quesenberry KH and Michaud M (eds). Forage livestock research needs for the Caribbean basin. University of Florida, Gainesville, p. 21-31

Pereira AV and Lédo FJS (2008) Melhoramento genético de Pennisetum purpureum. In Resende RMS, Valle CB and Jank L (eds.) Melhoramento de forrageiras tropicais. Embrapa Gado de Corte, Campo Grande, p. 89-116.

Pinheiro AA, Pozzobon MT, Valle CB, Penteado MIO and Carneiro VTC (2000) Duplication of the chromosome number of diploid Brachiaria brizantha plants using colchicine. Plant Cell Reports 19: 274-278
Resende RMS, Jank L, Valle CB and Bonato ALV (2004) Biometrical analysis and selection of tetraploid progenies of Panicum maximum using mixed model method. Pesquisa Agropecuária Brasileira 39: 335-341.

Santos-Garcia MO, Resende RMS, Chiari L, Zucchi MI and Souza AP (2010) Mating systems in tropical forages: Stylosanthes capitata Vog. and Stylosanthes guianensis (Aubl.) Sw. Euphytica DOI 10.1007/s10681-010-0293-x.

Savidan YH (1982) Nature et hérédité de l'apomixie chez Panicum maximum Jacq. (Nature and heredity of apomixis in Panicum maximum Jacq). ORSTOM, Paris, 159p. (ORSTOM Travaux et Documents 153)

Savidan YH (2000) Apomixis: genetics and breeding. Plant Breeding Reviews 18: 13-86.

Savidan YH, Jank L, Costa JCG and Valle CB (1989) Breeding Panicum maximum in Brazil: 1. Genetic resources, modes of reproduction and breeding procedures. Euphytica 41: 107-112.

Simeão RM, Resende MDV, Laura VA, Jank L and Valle CB (2006) Genotypic evaluation of accessions and individual selection in Stylosanthes spp. by simulated BLUP method. Crop Breeding and Applied Biotechnology 6: 253-260.

Simioni C and Valle CB (2009) Chromosome duplication in Brachiaria (A.Rich.) Stapf allows intraspecific crosses. Crop Breeding and Applied Biotechnology 9: 328-334.

Souza SF, Auad AM and Lédo FJS (2010) Genetic variability in Brachiaria ruziziensis for resistance to spittlebugs. Crop Breeding and Applied Biotechnology 10: 83-88.

Valle CB, Jank L and Resende RMS (2009) O melhoramento de forrageiras tropicais no Brasil. Revista Ceres 56: 460-472.

Valle CB, Macedo MCM, Euclides VPB, Jank L and Resende RMS (2010) Gênero Brachiaria. In Fonseca DM and Martuscello JA (eds.) Plantas forrageiras. Editora UFV, Viçosa, p. 30-77.

Valls JFM and Pizarro EA (1994) Collection of wild Arachis germplasm. In Kerridge PC and Hardy B (eds.) Biology and agronomy of forage Arachis. CIAT, Colombia, p. 19-27. 